\title{
Prokaryotic aminopeptidase activity along a continuous salinity gradient in a hypersaline coastal lagoon (the Coorong, South Australia)
}

\author{
Thomas Pollet*1,2, Mathilde Schapira1,3, Marie-Jeanne Buscot ${ }^{1}$, Sophie C Leterme1,4, James G Mitchell ${ }^{1}$ and \\ Laurent Seuront 1,4,5,6
}

\begin{abstract}
The distribution and aminopeptidase activity of prokaryotes were investigated along a natural continuous salinity gradient in a hypersaline coastal lagoon, the Coorong, South Australia. The abundance of prokaryotes significantly increased from brackish to hypersaline waters and different sub-populations, defined by flow cytometry, were observed along the salinity gradient. While four sub-populations were found at each station, three additional ones were observed for $8.3 \%$ and $13.4 \%$, suggesting a potential modification in the composition of the prokaryotic communities and/or a variation of their activity level along the salinity gradient. The aminopeptidase activity highly increased along the gradient and salinity appeared as the main factor favouring this enzymatic activity. However, while the aminopeptidase activity was dominated by free enzymes for salinities ranging from $2.6 \%$ to $13.4 \%$, cell-attached aminopeptidase activity was predominant in more saline waters (i.e. 15.4\%). Changes in substrate structure and availability, strongly related to salinity, might (i) modify patterns of both aminopeptidase activities (free and cellassociated enzymes) and (ii) obligate the prokaryotic communities to modulate rapidly their aminopeptidase activity according to the nutritive conditions available along the gradient.
\end{abstract}

\section{Findings}

Dissolved proteins and peptides are important sources of energy and nitrogen in aquatic systems [1,2], but they must be hydrolysed to amino acids and oligopeptides to be useable by prokaryotes. Following the development of sensitive methods using fluorogenic substrates [3], proteolytic activity in natural aquatic systems has been assessed by measuring the activity of leucine-aminopeptidase as a model enzyme [4]. However, microbial cells living in aquatic systems are influenced by a variety of environmental factors which affect the molecular control of their enzyme synthesis. Among these variables, salinity has been identified as a major driving force in both the composition of bacterioplankton and their efficiency in degrading dissolved organic carbon (DOC) [5]. Previous studies focusing on the effect of salinity on the composition and metabolic activity of bacterial communities were

* Correspondence: thomas.pollet@thonon.inra.fr

1 School of Biological Sciences, Flinders University, GPO Box 2100, Adelaide SA 5001, Australia

Full list of author information is available at the end of the article mainly conducted in estuaries where salinity typically did not exceed 5\% [6] and the effect of higher salinity conditions was mainly investigated in highly saline ponds from solar salterns [7]. To our knowledge, little is still known about the dynamic of prokaryotic aminopeptidase activity along natural continuous hypersaline gradients. The objective of this study was to investigate the changes in aminopeptidase activity of prokaryotic communities identified using flow cytometry from brackish to hypersaline waters.

The Coorong is a South Australian shallow coastal lagoon characterized by a strong salinity gradient with salinity continuously ranging from brackish (1.8\%) to hypersaline (15.5\%). Constrained between the last interglacial dune and the modern dune that has been established from the mid-holocene, this lagoon receives inputs from the ocean through the Murray Mouth and from underground and freshwater inputs from Lake Alexandrina and Lake Albert, which are the terminal system of the River Murray (Fig. 1). If freshwater inputs lead to lower salinities in the northwest part of the Coorong, the excess in evapora- 


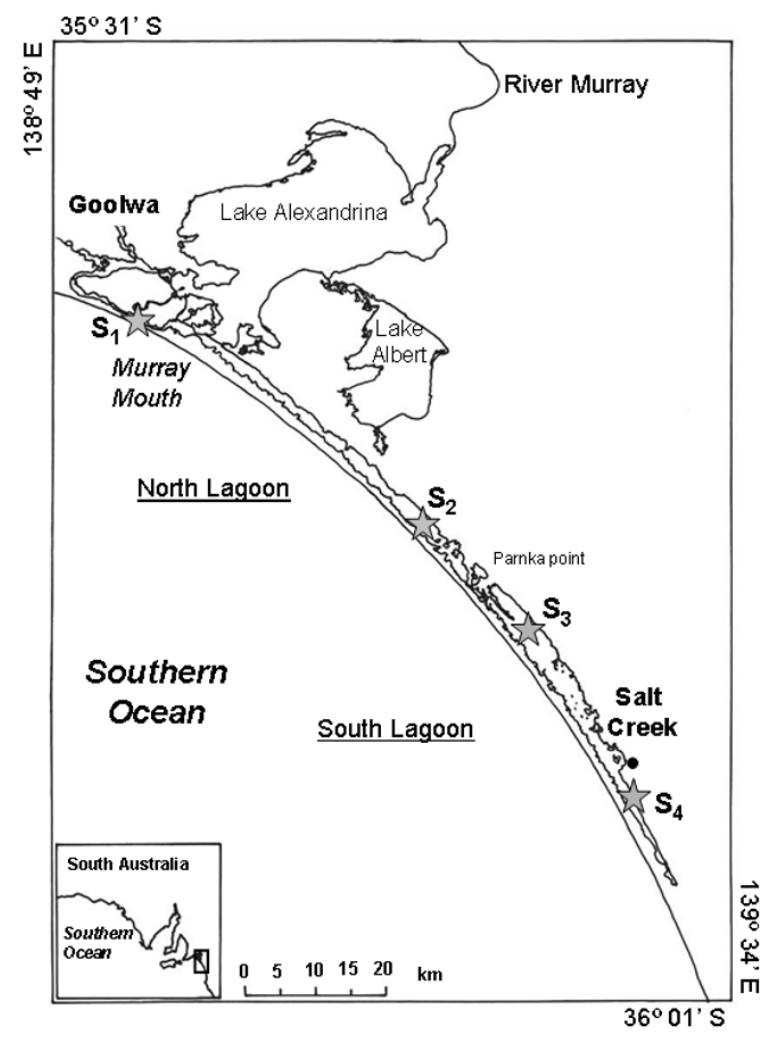

Figure 1 Study site (the Coorong, South Australia) and the 4 sampling stations (iv) from $\mathrm{S}_{1}$ to $\mathrm{S}_{4}$

tion over precipitation increases salinity along the northsouth axis, especially during the summer period.

Sub-surface samples were collected at 4 stations $\left(\mathrm{S}_{1}, \mathrm{~S}_{2}, \mathrm{~S}_{3}\right.$ and $\mathrm{S}_{4}$; Fig. 1) characterized by increasing salinities, i.e. $2.6 \%, 8.3 \%, 13.4 \%$ and $15.4 \%$. Temperature $\left({ }^{\circ} \mathrm{C}\right)$, conductivity $\left(\mathrm{mS} \mathrm{cm}^{-1}\right)$ and dissolved oxygen concentrations (DO; $\mathrm{mg} \mathrm{l}^{-1}$ ) were recorded using a YSI 85 (Fondriest) multiparameter probe. Salinity (\%) was calculated from temperature and conductivity following Fofonoff and Millard [8]. Water samples were collected at each station using acid-washed 1-liter borosilicate bottles.

Water temperature ranged between 25.2 and $27.7^{\circ} \mathrm{C}$. DO concentrations decreased from $3.46 \mathrm{mg} \mathrm{l}^{-1}$ in $\mathrm{S}_{1}$ to 1.48 $\mathrm{mg} \mathrm{l}^{-1}$ in $\mathrm{S}_{4}$ (Table 1). Concentration of suspended particular matter (SPM), determined following Hewson et al [9], increased from $38 \mathrm{mg} \mathrm{l}^{-1}$ at $\mathrm{S}_{1}$ to $540 \mathrm{mg} \mathrm{l}^{-1}$ at $\mathrm{S}_{4}$ (Table 1). Nutrient concentrations were determined in the field using a portable LF 2400 photometer according to standard colorimetric methods for $\mathrm{NH}_{4}^{+}$(Indophenol blue), $\mathrm{NO}_{2}^{-}$(Naphtylethylene diamine), $\mathrm{NO}_{3}^{-}$(Naphtylethylene diamine after zinc reduction) and $\mathrm{PO}_{4}^{3-}$ (Ascorbic acid reduction). Ammonium was the most abundant form of nitrogen with concentrations consistently increasing from $2.5 \mu \mathrm{M}$ in $\mathrm{S}_{1}$ to more than $110 \mu \mathrm{M}$ in $\mathrm{S}_{3}$ and $\mathrm{S}_{4}$. Phosphate concentrations were low at $\mathrm{S}_{1}, \mathrm{~S}_{2}$ and $\mathrm{S}_{3}$ (i.e. $\left.<8.5 \mu \mathrm{M}\right)$ whereas $\mathrm{S}_{4}$ was characterized by high phosphate concentrations $(>50 \mu \mathrm{M})$. Chl $a\left(\mu \mathrm{g} \mathrm{l}^{-1}\right)$, determined following Strickland and Parson [10] using a Turner 450 fluorometer after extraction in methanol of the samples collected on glass-fiber filters, were low at $S_{1}$, $\mathrm{S}_{2}$ and $\mathrm{S}_{4}$ (i.e. $<3 \mu \mathrm{g} \mathrm{l}^{-1}$ ). In contrast, $\mathrm{S}_{3}$ was characterized by relatively high $\mathrm{Chl} a$ concentrations $\left(13.5 \mu \mathrm{g} \mathrm{l}^{-1}\right.$; Table 1).

Prokaryotic populations were identified and enumerated by flow cytometry (FCM) using a FACScanto flow cytometer. Samples were fixed and prepared following Brussaard [11]. Sub-populations were discriminated based on the differences in SYBR-I Green fluorescence and rightangle light scatter (SSC). Fluorescent beads $1 \mu \mathrm{m}$ in diameter were added to all samples as an internal standard. Working bead concentrations were estimated after each FCM session under epifluorescent microscopy to ensure reliability of the bead concentration and all FCM parameters were normalized to bead concentration and fluorescence. Finally, populations were identified and enumerated using WinMDI 2.9 ( $\odot$ Joseph Trotter) flow cytometry analysis software. No significant differences were found between FCM counts and epifluorescence microscopy (EM) counts conducted at each station (Wilcoxon-Mann-Whitney U-test, $\mathrm{n}=5, \mathrm{p}>0.05$ ).

In accordance with previous observations from solar salterns [12], the abundance of prokaryotes showed a significant increase with salinity $(\mathrm{p}<0.05)$, with values ranging from $2.1 \times 10^{6} \mathrm{ml}^{-1}$ at $\mathrm{S}_{1}$ to $1.7 \times 10^{8} \mathrm{ml}^{-1}$ at $\mathrm{S}_{4}$ (Fig. 2). The high SPM and phosphate concentrations observed at the hypersaline station $\left(\mathrm{S}_{4}\right)$ are favourable to high microbial abundance [13-17]. In addition, the decrease in viral lysis and bacterivory as well as the rapid growth of bacteria under high salinity conditions (i.e. > 15\%) $[12,18]$, might also have contributed to the high prokaryotic abundance observed in the hypersaline part of the lagoon. The prokaryotic cytometric richness also varied along the gradient (Fig. 3). Four to seven discrete sub-populations of prokaryotes were identified along the salinity gradient. Four distinct sub-populations were observed at $\mathrm{S}_{1}(\mathrm{~S}=$ $2.6 \%$ ) and $\mathrm{S}_{4}(\mathrm{~S}=15.4 \%)$ (Fig. $\left.3 \mathrm{~A}\right)$ whereas 7 and 6 subpopulations were identified at $S_{2}(S=8.3 \%)$ and $S_{3}(S=$ $13.4 \%$ ), respectively (Fig. 3B). The variability of the prokaryotic cytometric richness observed along the salinity gradient (Fig. 3C) could reflect a modification of both bacterial populations and their activity level [19]. It is now well known that salinity represents one of the main factors structuring the distribution of prokaryotic assemblages, favouring the dominance of some groups adapted 
Table 1: Physical and chemical parameters measured along the salinity gradient.

\begin{tabular}{|c|c|c|c|c|}
\hline Parameters & S1 & S2 & S3 & S4 \\
\hline $\mathrm{S}(\%)$ & 2.6 & 8.3 & 13.4 & 15.4 \\
\hline $\mathrm{T}\left({ }^{\circ} \mathrm{C}\right)$ & 27.7 & 24.2 & 26.6 & 25.2 \\
\hline $\mathrm{DO}\left(\mathrm{mg} \mathrm{l}^{-1}\right)$ & 3.4 & 3.7 & 2.2 & 1.4 \\
\hline$\left[\mathrm{NH}_{4}^{+}\right](\mu \mathrm{M})$ & 2.5 & 5.3 & $>110$ & $>110$ \\
\hline$\left[\mathrm{NO}_{3}^{-}\right]+\left[\mathrm{NO}_{2}^{-}\right](\mu \mathrm{M})$ & $<1.6$ & 2.9 & $<1.6$ & 1.7 \\
\hline$\left[\mathrm{PO}_{4}{ }^{3-}\right](\mu \mathrm{M})$ & 1.0 & 8.4 & 1.0 & $>50$ \\
\hline$[\mathrm{Chl} a]\left(\mu \mathrm{g} \mathrm{l}^{-1}\right)$ & 1.2 & 2.5 & 13.5 & 1.3 \\
\hline $\mathrm{SPM}\left(\mathrm{mg} \mathrm{l}^{-1}\right)$ & 38.0 & 182.7 & 477.0 & 540.0 \\
\hline
\end{tabular}

Salinity $(\mathrm{S} ; \%)$ and temperature $\left(\mathrm{T}^{\circ}{ }^{\circ} \mathrm{C}\right)$. Dissolved oxygen $\left(\mathrm{DO} ; \mathrm{mgl}^{-1}\right)$, ammonium $\left(\left[\mathrm{NH}_{4}{ }^{+}\right] ; \mu \mathrm{M}\right)$, nitrate + nitrite $\left(\left[\mathrm{NO}_{3}{ }^{-}\right]+\left[\mathrm{NO}_{2}{ }^{-}\right] ; \mu \mathrm{M}\right)$, phosphate $\left(\left[\mathrm{PO}_{4}{ }^{3-}\right] ; \mu \mathrm{M}\right)$, Chlorophyll $a\left([\mathrm{Chl} a] ; \mu \mathrm{g} \mathrm{l}^{-1}\right)$ and Suspended Particulate Matter (SPM; $\left.\mathrm{mg} \mathrm{l}^{-1}\right)$ concentrations

at a particular salt concentration [20]. Along the Coorong, the highest cytometric richness was observed at $8.4 \%$ (7 sub-populations, station $\mathrm{S}_{2}$ ) and $13.4 \%$ (6 subpopulations, station $\mathrm{S}_{3}$ ). In contrast, the cytometric richness was much lower under hypersaline conditions $\left(\mathrm{S}_{4}\right)$ and in the brackish area $\left(\mathrm{S}_{1}\right)$. The elevated nutrient, Chl $a$ and SPM concentrations recorded in this part of the lagoon, may have favoured this richness through a strong resource competition which is known to prevent the proliferation and the dominance of some communities.

However, the variability in cytometric richness observed along the gradient could also reflect a change in prokaryotic activity level with salinity. This is consistent with previous results [21] showing that salinity selectively affects certain groups leading to a marked modification in their growth efficiency and cell-specific activity.

Aminopeptidase activity was estimated using the fluorogenic substrate analog, L-leucine-4-methyl-coumarinyl-

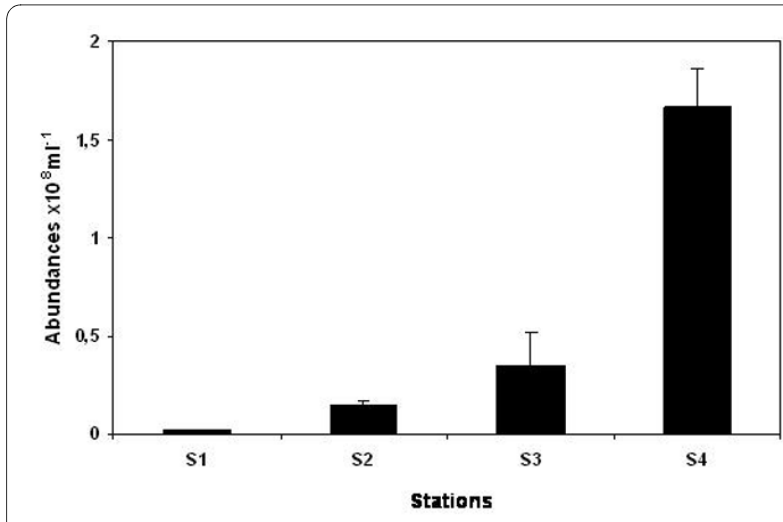

Figure 2 Prokaryotic abundances $\left(\times 10^{8} \mathrm{ml}^{-1}\right)$ along the salinity gradient. The error bars are the standard deviations. 7amide (Leu-AMC). AMC fluorescence was determined at $340 \mathrm{~nm}$ (excitation) and $440 \mathrm{~nm}$ (emission), with a spectrofluorometer (Hitachi Fluorescence Spectrophotometer, Model F-3000) previously calibrated. Total enzymatic activity (i.e. free enzymes dissolved in water and cell surface bound enzymes) and free extracellular enzymatic activity were estimated for each sampling site. For free enzymatic activity, water samples were previously gravity filtered through $0.2 \mu \mathrm{m}$ pore size filters. Before each spectrophotometry analysis, subsamples without substrates were used as blanks to determine the background fluorescence of the samples at each sampling station. Aminopeptidase activity was quantified through Michaelis-Menten kinetic parameters: the highest rate of substrate hydrolysis $V_{\max }\left(\mu \mathrm{M} \mathrm{h}^{-1}\right)$ and the half-saturation constant for the enzyme $K_{m}(\mu \mathrm{M})$, which indicates the enzyme affinity to the substrate.

In the present study and as previously described in solar salterns [7], the aminopeptidase activity of prokaryotes increased with salinity (Fig. 4A). The significant positive correlation observed between abundance and aminopeptidase activity is consistent with previous observations $[7,22]$. Specifically, the increase in the potential activity $\left(V_{\text {max }}\right.$ ) from station $\mathrm{S}_{1}$ to station $\mathrm{S}_{4}$ indicates that hydrolysis rates increase with salinity. In addition, given the increase in SPM concentrations by more than one order of magnitude between stations $S_{1}$ and $S_{4}$ (Table 1) and to the extent that prokaryotic metabolism reflects the ambient substrate availability, this increase in aminopeptidase activity suggests that the quality of organic matter may strongly differ along the salinity gradient and may indicate the existence of a gradient in the protein availability from brackish to hypersaline stations. This hypothesis is congruent with previous observations [23,24] showing 

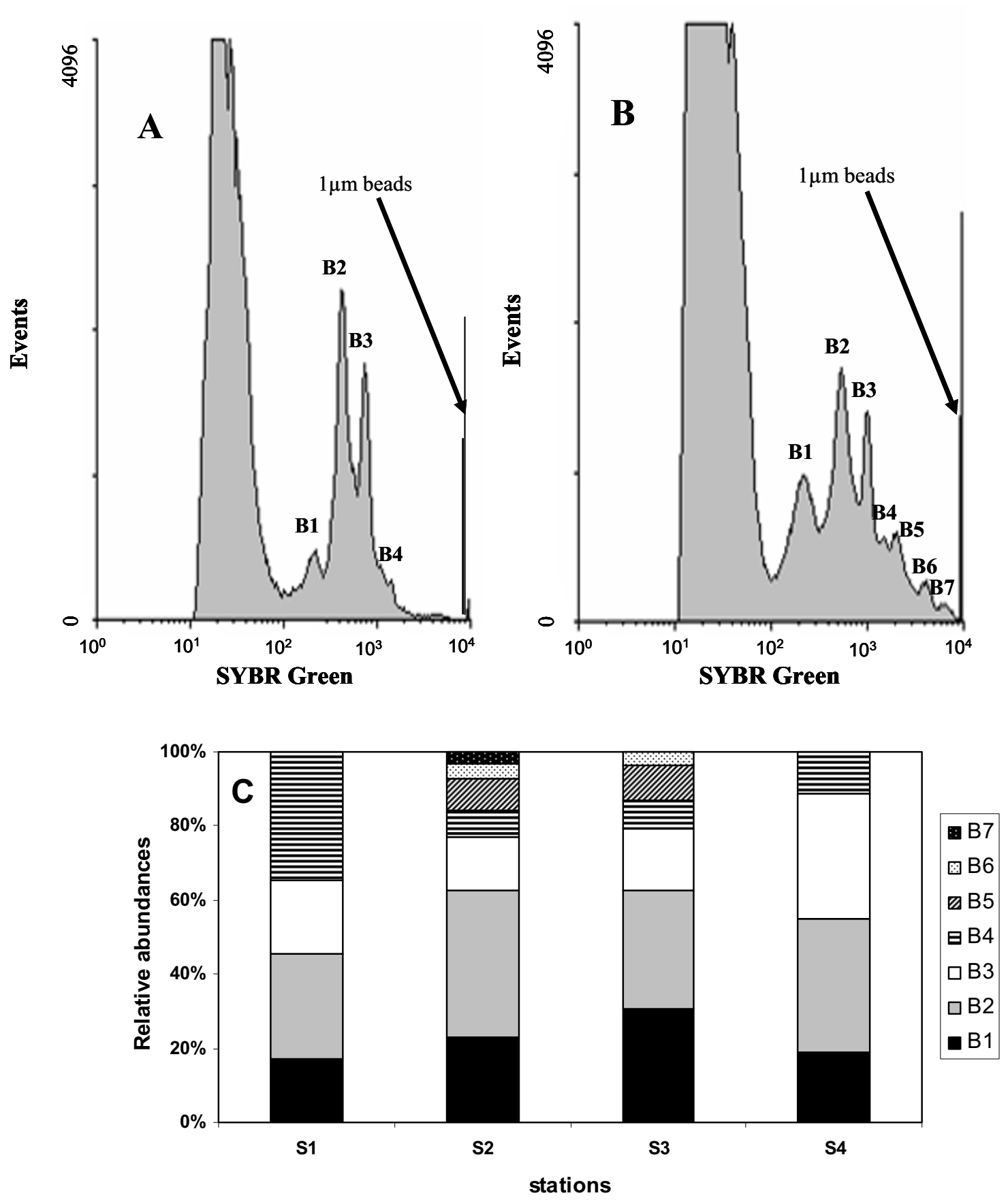

Figure 3

Figure 3 Cytometric differentiation of prokaryotic populations. (A) Shows results obtained from S4. Four prokaryotic sub-populations were identified; the histogram plot of green fluorescence shows 4 peaks relating to sub-populations of increasing DNA content (B1 to B4). (B) Shows results obtained from S2. Seven prokaryotic sub-populations were identified; the histogram plot of green fluorescence shows 7 peaks relating to sub-populations of increasing DNA content (B1 to B7). Sub-populations differed through their green fluorescence and side scatter, and therefore were not classified into high and low DNA-subpopulations but as different discrete populations. (C) Relative abundances (\%) of cytometrically-defined subpopulations along the salinity gradient from $\mathrm{S}_{1}$ to $\mathrm{S}_{4}$ 

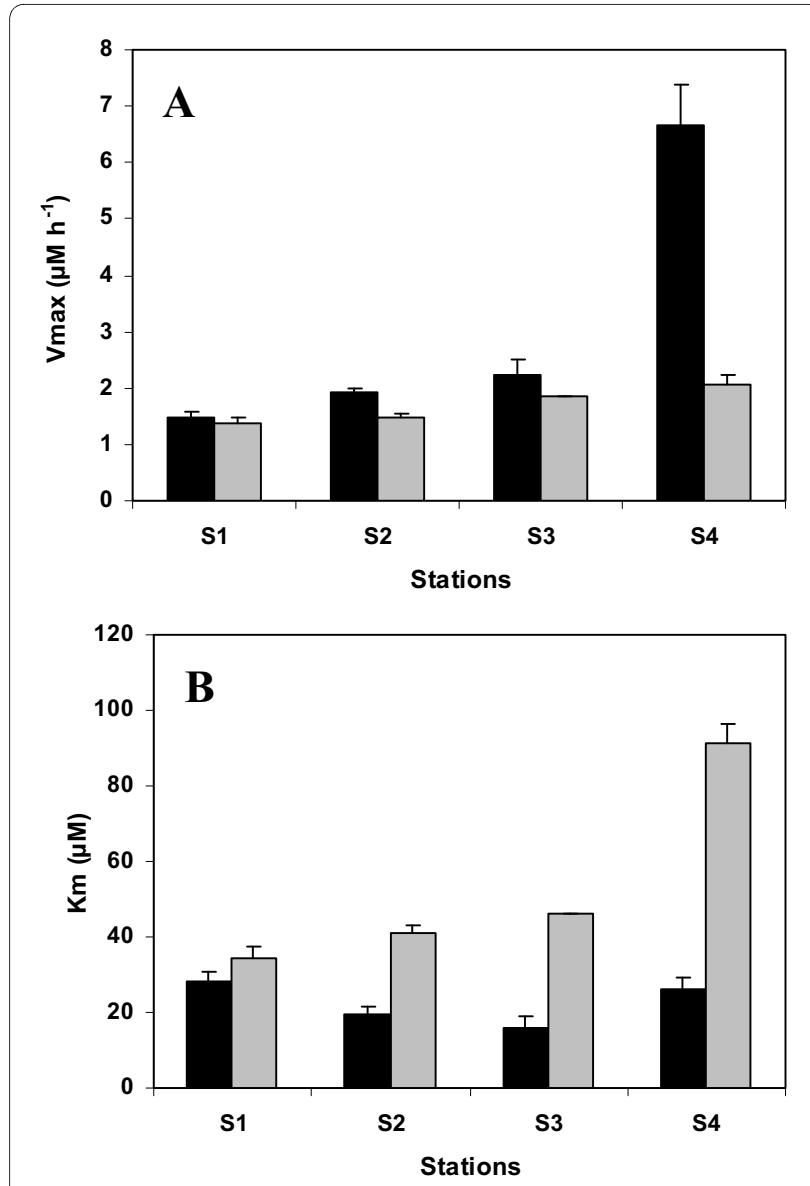

Total enzymes

Free enzymes

Figure 4

Figure 4 Aminopeptidase activity along the salinity gradient. (A) maximum enzymatic velocity, $V_{\max }\left(\mu \mathrm{M} \mathrm{h}^{-1}\right)$, and (B) affinity with the substrate, $K_{m}(\mu M)$ from $S_{1}$ to $S_{4}$. Total enzymatic and free enzymatic activities are shown in black and grey, respectively. The error bars represent the standard deviations.

that dissolved organic nitrogen (DON) and protein concentrations increased southwards along the Coorong. While this issue is well beyond the objectives of the previous work, information on the quality and quantity of organic matter would be a step forward in the understanding of the role played by salinity in prokaryotic metabolic activity. The observed increase in aminopeptidase activity beyond $15 \%$ (Fig. 4) contradicts previous results suggesting that salinity greater than $12 \%$ hampers aminopeptidase activity [7]. This difference may be related to the uniqueness of the Coorong which is characterized by a strong continuous salinity gradient with specific dynamics and functional performance of bacterioplankton communities in contrast to solar salterns considered as steady-state ecosystems with well-adapted and estab- lished communities. Further work would nevertheless be needed to confirm and generalize this potential fundamental difference between solar salterns and hypersaline lagoons.

Free and cell-associated aminopeptidase activities exhibit different patterns in relation to salinity. From $2.6 \%$ to $13.4 \%$, free aminopeptidase activity seems to be favoured; for higher salinity (15.4\%), cell-associated aminopeptidase activity is preferred (Fig. 4A). Under the assumption that protein substrates were likely more available at the hypersaline station $\left(\mathrm{S}_{4}\right)$, this observation is congruent with Hollibaugh and Azam 's conclusions[25]. Free enzymes could be less important in the protein degradation and close physical association between prokaryotes and proteins would be necessary for efficient protein degradation. This may explain the dominance of cell-associated aminopeptidase activity observed at the hypersaline station. In addition, the changes in ionic strength related to salinity might affect the structure of substrate molecules and consequently the activity of extracellular enzymes [5]. Indeed, the solubility of proteins is known to be profoundly affected by the ionic strength and particularly by the presence of divalent cations [25]. This low solubility of proteins under hypersaline conditions might favour the prokaryote/protein association and might thus explained the higher cell-associated aminopeptidase activity observed at the hypersaline station. Moreover, the increase in SPM concentration along the salinity gradient may also favour the creation of microscale environments leading to local hotspots of prokaryotes attached to particles [26]. This may also explained the observed transition from free to cell-attached aminopeptidase activity along the gradient (Fig. 4A) and the increase in substrate affinity observed at station $\mathrm{S}_{4}$ (Fig. 4B) for high salinity values. It is finally stressed that free-aminopeptidase activity is unlikely to have been contaminated by cell lysis, hence over-estimated, because of the non-destructive gravity filtration conducted here. Note, however, that at the highest salinity, free enzymes might aggregate with particulate matter, leading to an overestimation of the cell-associated enzymatic activity. While this is beyond the aims of the present work, further work is needed to assess the contribution of salinity in bounding free enzymes to particulate material.

In accordance with previous reports, this first study performed along a continuous salinity gradient has shown that the increase in salinity appeared as the main factor favouring aminopeptidase activity. However, both aminopeptidase activities (free and cell-associated enzymes) are also influenced by the availability and structure of suspended materials that is susceptible of strong changes along the salinity gradient. Prokaryotic communities have then to rapidly modulate their aminopeptidase activities 
to optimize their fitness in response to the variability of the nutritive conditions along the salinity gradient. Given the key role played by microbial communities in the functioning of aquatic systems, these results stress the need to extend our knowledge concerning the effect of salinity on the dynamics and activity of microbial communities in natural systems particularly in the context of global change which particularly affects local ecosystems, such as the Coorong, through changes in salinity related to modifications of freshwater discharge and evaporation. Further work is thus needed to assess the interplay between salinity and the global enzymatic activity of prokaryotic communities.

\section{Competing interests}

The authors declare that they have no competing interests.

\section{Authors' contributions}

TP conducted the sampling experiments, performed the abundance and aminopeptidase activity analyses and drafted the manuscript. MS conducted the sampling experiments, participated in abundance and enzymatic activity analyses and drafted the manuscript. MJB and SCL participated in sampling experiments. JGM participated in the design of study. LS designed the study, conducted the sampling experiments, and drafted the manuscript. All the authors have read and approved the final manuscript.

\section{Acknowledgements}

The authors wish to thank Dr. S. Bailey from the Flow Cytometry Unit of the Flinders Medical Centre, for providing technical support during the flow cytometry work. This work was supported financially and infrastructurally by the Australian Research Council (Discovery Projects DP0664681 and DP0666420) and Flinders University. Professor Seuront is the recipient of an Australian Professorial Fellowship (project number DP0988554).

\section{Author Details}

1School of Biological Sciences, Flinders University, GPO Box 2100, Adelaide SA 5001, Australia, 2UMR CARRTEL, Centre Alpin de Recherche sur les Réseaux Trophiques des Ecosystèmes Limniques, Station d'Hydrobiologie Lacustre, Université de Savoie, 75 avenue de Corzent, BP 511, 74203 Thonon les Bains Cedex, France, 3Southern Ocean Group, Dept. of Zoology \& Entomology, Rhodes University, PO Box 94, Grahamstown 6140, South Africa, 4South Australian Research and Development Institute, Aquatic Sciences, West Beach SA 5022, Australia, ${ }^{5}$ Center for Polymer Studies, Department of Physics, Boston University, 590 Commonwealth Avenue, Boston, MA 02215, USA and 6 Centre National de la Recherche Scientifique (France

Received: 23 December 2009 Accepted: 30 April 2010

Published: 30 April 2010

\section{References}

1. Wheeler PA, Kirchman DL: Utilization of inorganic and organic nitrogen by bacteria in marine systems. Limnol Oceanogr 1986, 31:998-1009.

2. McCarthy MD, Benner R, Hedges J: Major bacterial contribution to marine dissolved organic nitrogen. Science 1998, 281:231-234

3. Hoppe HG: Significance of exoenzymatic activities in the ecology of brackish water: measurements by means of methyllumbeliferylsubstrates. Mar Ecol Prog Ser 1983, 11:299-308.

4. Hoppe HG, Arnosti C, Herndl GF: Ecological significance of bacterial enzymes in the marine environment. Enzymes in the environment. Activity Ecology and Applications, New York 2002:73-107.

5. Langenheder S, Kisand V, Wikner J, Tranvik LJ: Salinity as a structuring factor for the composition and performance of bacterioplankton degrading riverine DOC. FEMS Microbiol Ecol 2003, 45:189-202.

6. Cunha MA, Almeida MA, Alcântara F: Ectoenzymatic activity and glucose heterotrophic metabolism in a shallow estuary (Ria de Aveiro, Portugal): influence of bed sediments and salt marshes. Acta Oecol 2003, 24:97-107.
7. Park JS, Choi DH, Hwang CY, Park GJ, Cho BC: Seasonnal study on ectoenzyme activities, carbohydrate concentrations, prokaryotic abundance and production in solar saltern in Korea. Aquat Microb Ecol 2006, 43:153-163

8. Fofonoff N, Millard RC: Algorithms for computation o fundamental properties of seawater. In UNESCO Tech Pap Mar Sci Volume 44. UNESCO, Paris; 1983.

9. Hewson I, O'Neil JM, Fuhrman JA, Dennison WC: Virus-like particles distribution and abundances in sediments and overlaying waters along eutrophication gradients in two tropical estuaries. Limnol Oceanogr 2001, 46:1734-1746.

10. Strickland JDH, Parsons TR: A practical handbook of seawater analysis. Bull Fish Res Board Can 1972, 167:1-311.

11. Brussaard CPD: Optimization of procedures for counting viruses by flow cytometry. Appl Environ Microbiol 2004, 70:1506-1513.

12. Pedrós-Alió C, Calderón-Paz Jl, Maclean MH, Medina G, Marrasé C, Gasol JM, Guixa-Boixereu N: The microbial food web along salinity gradient. FEMS Microbiol Ecol 2000, 32:143-155.

13. Zweifel UL, Norman B, Hagstrom A: Consumption of dissolved organic carbon by marine bacteria and demand for inorganic nutrients. Mar Ecol Progr Ser 1993, 101:23-32.

14. Pomeroy LR, Sheldon JE, Sheldon WM, Peters F: Limit of growth and respiration in bacterioplankton in the Gulf of Mexico. Mar Ecol Prog Ser 1995, 117:259-268.

15. Thingstad TF, Zweifel UL, Rassoulzadegan F: P limitation of heterotrophic bacteria and phytoplankton in the north-west Mediterranean. Limnol Oceanogr 1998, 43:88-94.

16. Becquevort S, Bouvier T, Lancelot C, Gauwet G, Deliat G, Egorov VN, Popovichev VN: The seasonal modulation of organic matter utilization by bacteria in the Danube-Black Sea mixing zone. Est Coast Shelf Sci 2002, 54:337-354.

17. Huston AL, Deming JW: Relationships between microbial extracellular enzymatic activity and suspended and sinking particulate organic matter: seasonal transformations in the North Water. Deep Sea Res Part // 2002, 49:5211-5225.

18. Guixa-Boixereu N, Calderon-Paz Jl, Heldal M, Bratbak G, Pedrós-Alió C: Viral lysis and bacterivory as prokaryotic loss factors along a salinity gradient. Aquat Microb Ecol 1996, 11:215-227.

19. Bouvier TC, Del-Giorgio PA, Gasol JM: A comparative study of the cytometric characteristics of high and low nucleic-acid bacterioplankton cells from different aquatic ecosystems. Environ Microbiol 2007, 9:2050-2066.

20. Casamayor EO, Massana R, Benlloch S, Ovreas L, Diez B, Goddard VJ, Gasol JM, Joint I, Rodriguez-Valera F, Pedros-Alio C: Changes in archaeal, bacterial and eukaryal assemblages along a salinity gradient by comparison of genetic fingerprinting methods in a multipond solar saltern. Environ Microbiol 2002, 4:338-348.

21. Del Giorgio PA, Bouvier TC: Linking the physiologic and phylogenetic successions in free-living bacterial communities along an estuarine salinity gradient. Limnol Oceanogr 2002, 47:471-486.

22. Cunha MA, Almeida MA, Alcântara F: Patterns of ectoenzymatic and heterotrophic bacterial activities along a salinity gradient in a shallow tidal estuary. Mar Ecol Prog Ser 2000, 204:1-12.

23. Ford PW: Biogeochemistry of the Coorong: review and identification of future research requirements. In Water for a Healthy Country National Research Flagship CSIRO Canberra; 2007.

24. Krull E, Lamontagne S, Haynes D, Broos K, McKirdy D, McGowan J, Gell P, Wakelin S: Changes in organic matter chemistry in the Coorong lagoons over space and time. In Water for a Healthy Country National Research Flagship CSIRO Canberra, ACT, Australia; 2008.

25. Hollibaugh JT, Azam F: Microbial degradation of dissolved proteins in seawater. Limnol Oceanogr 1983, 28:1104-1116.

26. Azam F: Microbial control of oceanic carbon flux: the plot thickens. Science 1998, 280:694-696.

doi: 10.1186/1746-1448-6-5

Cite this article as: Pollet et al., Prokaryotic aminopeptidase activity along a continuous salinity gradient in a hypersaline coastal lagoon (the Coorong, South Australia) Saline Systems 2010, 6:5 